\title{
Effects of gall induction by Epiblema strenuana on gas exchange, nutrients, and energetics in Parthenium hysterophorus
}

\author{
S.K. FLORENTINE ${ }^{1,3, *}$, A. RAMAN ${ }^{2}$ and K. DHILEEPAN ${ }^{1}$ \\ ${ }^{1}$ Tropical Weeds Research Centre, Queensland Department of Natural Resources and \\ Mines, Charters Towers, QLD 4820, Australia; ${ }^{2}$ The University of Sydney, P.O. Box \\ 883, Orange, NSW 2800, Australia; ${ }^{3}$ Centre for Environmental Management, School \\ of Sciences \& Engineering, University of Ballarat, P.O. Box 663, Ballarat, VIC 3353, \\ Australia \\ *Author for correspondence; e mail: s.florentine@ballarat.edu.au
}

\begin{abstract}
Gall induction by arthropods results in a range of morphological and physiological changes in their host plants. We examined changes in gas exchange, nutrients, and energetics related to the presence of stem galls on Parthenium hys terophorus L. (Asteraceae) induced by the moth, Epiblema strenuana Walker (Lepi doptera: Tortricidae). We compared the effects of galls on P. hysterophorus in the rosette (young), pre flowering (mature), and flowering (old) stages. Gall induction reduced the leaf water potential, especially in flowering stage plants. In young and mature stage plants, galling reduced photosynthetic rates considerably. Gall induction reduced the transpiration rate mostly in mature plants, and this also diminished stomatal conductance. Energy levels in most galls and in shoot tissue immediately below the galls were significantly higher than the energy levels in stem tissue imme diately above the galls, indicating that the gall acts as a mobilizing sink for the moth. Galling had significant effects on concentrations of minerals such as boron, chloride, magnesium, and zinc. In galled plants, reduced leaf water potential and reduced rates of photosynthesis, transpiration, and stomatal conductance may have altered mineral element levels. These observed effects demonstrate that E. strenuana has the potential to regulate $P$. hysterophorus.
\end{abstract}

Key words: Asteraceae, biological control, changes in mineral contents, energetics, Epiblema strenuana, Parthenium hysterophorus, stem galling moth, Tortricidae

\section{Introduction}

Gall-inducing insects have highly specialized and intimate nutritional relationships with their host plants because such insects spend a major part of their life within the gall (Shorthouse and Rohfritsch, 1992; Raman, 1996). Galls arise from modification of the structure and 
metabolism of plants. Modifications, from simple removal of tissue (Dreger-Jauffret and Shorthouse, 1992) or physical damage to vascular tissue (Raman and Dhileepan, 1999), to complex manipulation of synthesis and transportation of host-plant nutrients (Rohfritsch, 1988; Bronner, 1992) affect the life history performance of host plants (Abrahamson and Weis, 1987). Gall induction by insects reduces photosynthetic and transpiration efficiencies, stomatal conductance, and water potential in plants (Flinn et al., 1990; Larson, 1998), eventually leaving the host plant stressed (Abrahamson and Weis, 1987; Raman, 1994; Florentine et al., 2001). The gall becomes a sink for nutrients (Kirst and Rapp, 1974; Larson and Whitham, 1991; Fay et al., 1993), which would otherwise be used by the plant for its growth and reproduction (Lalonde and Shorthouse, 1984; Raman and Abrahamson, 1995). Galls not only capture photoassimilates, but also mineral nutrients such as $\mathrm{Ca}, \mathrm{Cu}, \mathrm{Fe}, \mathrm{Mg}, \mathrm{Mn}, \mathrm{Ni}$, and $\mathrm{Zn}$ (Abrahamson and Weis, 1987; Bagatto and Shorthouse, 1991, 1994, 1997; Paquette et al., 1992).

Parthenium hysterophorus L. (Asteraceae) is a weed of national significance in Australia. Therefore, the biology and ecology of $P$. hysterophorus and of several arthropods that might prove useful as biological control agents are currently being investigated (McFadyen, 1992; Navie et al., 1996; Dhileepan and McFadyen, 1997). Two gallinducing insects, Epiblema strenuana Walker (Lepidoptera: Tortricidae) and Conotrachelus albocinereus Fiedler (Coleoptera: Curculionidae) are considered the most promising candidates likely to have a role in P. hysterophorus management (Florentine et al., 2001, 2002). Gall induction by E. strenuana reduces main shoot height, flower and leaf production, and shoot and root biomass in $P$. hysterophorus (Navie et al., 1998; Dhileepan and McFadyen, 2001). The galls also alter shoot structure and metabolic pathways of the plant (Raman and Dhileepan, 1999).

Parthenium hysterophorus is an annual herb with a deeply penetrating taproot and an erect shoot. As it grows, it branches profusely, and can reach heights up to $2 \mathrm{~m}$. Young plants form a rosette of leaves close to the soil surface. This plant grows vigorously, particularly during warmer months. Flowering usually commences 68 weeks after germination and a fully-grown plant can produce more than 25,000 florets in its lifetime, with each inflorescence bearing 45 seeds (Navie et al., 1996; Dhileepan et al., 2000).

Epiblema strenuana lays eggs on young leaves of $P$. hysterophorus. The gall-inducing larval stage specifically feeds on $P$. hysterophorus and the annual common ragweed (Ambrosia artemisiifolia L.). Emerging larvae mine the leaves briefly, and then move to the closest axillary 
vegetative buds. They enter stems by chewing the vegetative bud tissue, and this action induces galls. When the larvae cease to feed, the nutritive cells degenerate. Larvae pupate within the gall and the pupal stage ranges from 4 to 6 days. Adult moths emerge from the galls through a 'window' cut by the mature larvae before pupation (Raman and Dhileepan, 1999).

In this paper, we report our evaluation of the subtle effects of galling by the moth on $P$. hysterophorus by measuring gas exchange, mineral concentrations, and energy levels within galled shoots on different-aged plants; we examined the developmental stage of the host plant in which gas exchange is most affected and examined whether gall induction affects mineral nutrient concentration and energetics in the host plant.

\section{Materials and methods}

\section{Experimental procedures}

Seeds of $P$. hysterophorus were collected from the Plain Creek property $\left(21^{\circ} 29^{\prime} \mathrm{S}, 146^{\circ} 40^{\prime} \mathrm{E}\right)$ in northern Queensland in March 1999 . They were air-dried and stored at room temperature $\left(21^{\circ} \mathrm{C}\right)$ in labelled airtight containers until use. Seeds were sown in seedling trays $\left(35 \times 29 \times 5.5 \mathrm{~cm}^{3}\right)$ containing sterilized coarse sand. The trays were maintained in a greenhouse, and were placed in larger trays $\left(43 \times 30 \times 6 \mathrm{~cm}^{3}\right)$ to enable watering from below and to ensure minimal disturbance of the seedlings. Newly emerged seedlings bearing 23 leaves were transplanted into plastic pots $\left(20 \times 20 \mathrm{~cm}^{2}\right)$ containing commercial soil mixture. To obtain different developmental stages of the host plant, seedlings were transplanted on different dates. Gallbearing host plants in the rosette stage ( 34 weeks old, with galls immediately above the root collar), pre-flowering stage (5 6 weeks old, obtained shortly before the commencement of flowering), and flowering stage (7 8 weeks old, bearing flowers) were used in the experiments. About 250 mature galls also were obtained from Cardigan Station $\left(146^{\circ} 38.3^{\prime} \mathrm{S}, 20^{\circ} 13.5^{\prime} \mathrm{E}\right)$ located approximately $25 \mathrm{~km}$ northeast of the Tropical Weeds Research Centre (TWRC) at Charters Towers, North Queensland. Gall samples were immediately placed in plastic containers covered with wet muslin cloth (to avoid desiccation), and transported to TWRC. On the same day, galls containing E. strenuana larvae and pupae were transferred to insect-proof cages that were maintained in greenhouses for rearing adults. Newly emerged adult moths were used for initiating galls. 
Sixty similar-sized and single-stem, unbranched plants at the rosette, pre-flowering, and flowering stages (180 total) were randomly selected, labelled, maintained in the greenhouse and watered twice daily. Among the 60 plants of each stage, 30 randomly selected plants were placed in three insect-proof cages (10 plants/cage) and exposed to 10 pairs of E. strenuana adults/cage. A similar number of plants (30 each of the rosette, pre-flowering, and flowering stages) were maintained free of E. strenuana in separate insect-proof cages (10 plants/cage). Plants exposed to E. strenuana were monitored daily for signs of gall initiation. Plants on which frass appeared close to vegetative buds were considered gall-initiated plants and were transferred to new insect-proof cages.

\section{Gas exchange}

Gas exchange measurements were carried out on day 7, following exposure to E. strenuana (to coincide with larval entry into stem tissue) and day 12 (when the shoot showed signs of swelling, i.e., the gall). On each of these days ambient temperature was recorded (min. $29^{\circ} \mathrm{C}$; max. $31^{\circ} \mathrm{C}$ ). Five fully expanded leaves selected below the gall region from each of the three stages from galled plants and similar sized leaves from ungalled plants were selected randomly, and the photosynthetic rate, rate of transpiration, stomatal conductance, photosynthetically active radiation (PAR $>500 \mu \mathrm{mol} \mathrm{m}{ }^{2} \mathrm{~s}^{1}$ ), chamber temperature, and ambient humidity were measured. Recordings were made between 1200 and $1300 \mathrm{~h}$ using an open gas exchange system (LCA-3, Analytical Development Co., Hoddesdon, England) attached to the leaf chamber (PLC-301(3B)). Leaf water potential of excised leaves was determined using a pressure chamber (Model No. Mk 3005, Soil Moisture Equipment Co., Santa Barbara, California, USA) following Scholander et al. (1965). Dividing the actual measurement by the sum of measurements and multiplying by 100 provided percentage values.

\section{Mineral content}

In total, 427 galled plants and 891 ungalled plants were obtained from the Plain Creek property in April 1999. On the basis of morphology, the plants were categorized into rosette, pre-flowering, and flowering stages. From similar categories of plants, the leaves, stems, and roots (just below the root collar), were pooled in separately labelled plastic bags. Samples were dried in an oven at $80{ }^{\circ} \mathrm{C}$ for $24 \mathrm{~h}$. They were ground in an electric grinder (Retsch GmbH WRS 80c/29). From the ground samples, subsamples (approximately $5 \mathrm{~g}$ ) were taken and used in the mineral nutrient 
analysis. Nitrogen was assayed using the method of Sweeney and Rexroad (1987), minerals such as $\mathrm{Ca}, \mathrm{Cu}, \mathrm{Fe}, \mathrm{K}, \mathrm{Mg}, \mathrm{Mn}, \mathrm{Na}, \mathrm{P}, \mathrm{S}$, and $\mathrm{Zn}$ according to the method of McQuacker et al. (1979), chloride and nitrate according to Zall et al. (1959), and B following Wolf (1974).

\section{Energetics}

To examine energy levels, plants were collected from the Plain Creek property in April 1999, and transported to TWRC in a dry-ice chest ( 2 to $4{ }^{\circ} \mathrm{C}$ ). At $\mathrm{TWRC}$, these plants were segregated into rosette, preflowering, and flowering stages. Galls, shoot tissue $1 \mathrm{~cm}$ above galls, and shoot tissue $1 \mathrm{~cm}$ below galls (except the rosette stage plants that bear galls only immediately above the root collar, therefore only the tissue $1 \mathrm{~cm}$ above galls was available) were trimmed and dried at room temperature $\left(21^{\circ} \mathrm{C}\right)$. The samples were packed in labelled aluminium foil and dried in an oven at $4550{ }^{\circ} \mathrm{C}$ for $24 \mathrm{~h}$. Samples were ground individually in the electric grinder. The ground samples were then packed in fresh, labelled aluminium foil for energy estimation. Calorific values were estimated using a semimicro Gallenkamp ballistic bomb calorimeter (CBB 330; 500 \& THP-520 series; jacket thermometer 130 070) following the technique used by Raman and Abrahamson (1995).

\section{Data analysis}

Data were analyzed using the Super ANOVA software program (Abacus Concepts, Berkeley, California, USA) for obtaining two-way ANOVA and all pairwise multiple comparison procedures. Residual plots of each ANOVA were obtained to examine homogeneity of the variance.

\section{Results}

\section{Gas exchange}

Gall induction significantly reduced all measures of gas exchange by the host plant, although the effect of galling varied with the plant stage (Figure 1; Table 1). Effect of galling on all but leaf-water potential also varied according to gall age. The difference in responses of different plant stages to galling also varied with gall age for transpiration rate and stomatal conductance.

Galls had a significant effect on leaf-water potential $(p<0.001)$ (Figure 1; Table 1). Reduction in leaf-water potential due to gall 
(a)
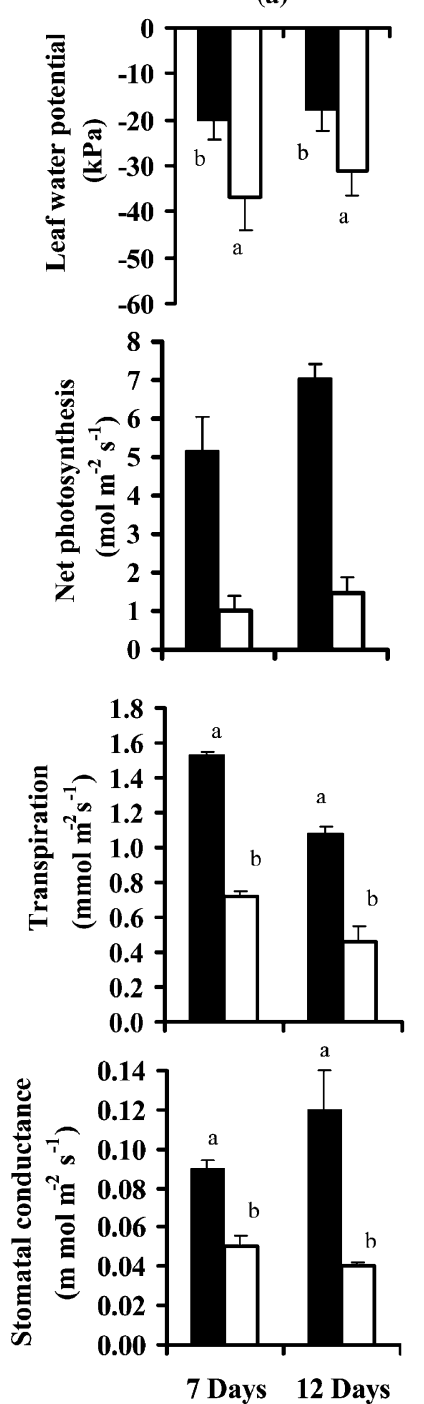

(b)
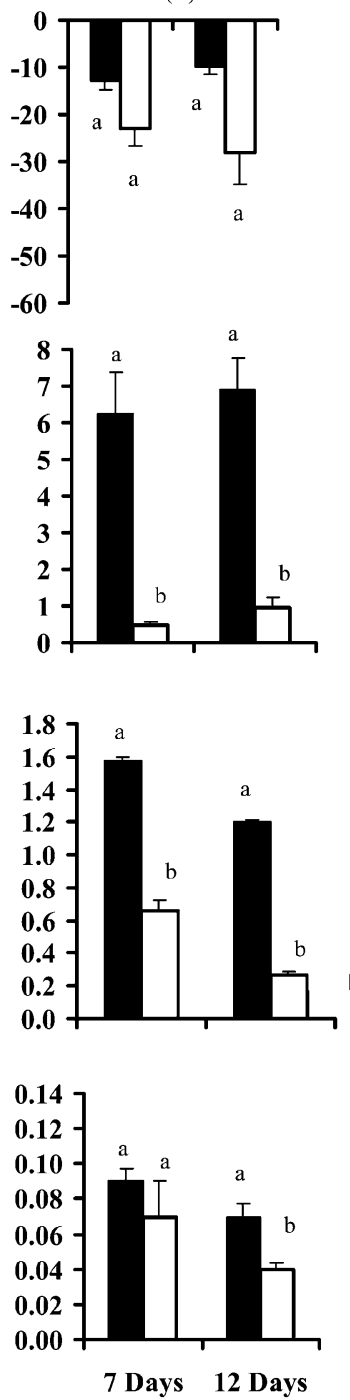

Days after gall-initiation (c)
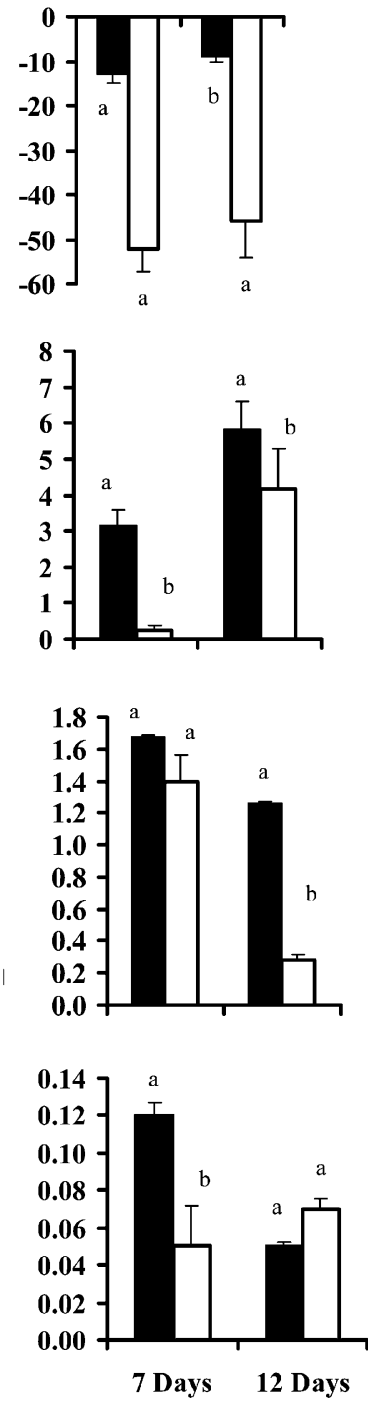

Figure 1. Leaf water potential, net photosynthesis, transpiration, and stomatal con ductance of ungalled (solid) and galled (open) rosette (a), pre flowering (b), and flow ering (c) stages of $P$. hysterophorus. Values are means. Same letters indicate means are not statistically different when tested with Tukey's HSD test. Vertical bars indicate standard errors.

induction was greater (71 $78 \%$ ) in the flowering stage than in the rosette (41 45\%) and pre-flowering stages (42 67\%) (Figure 1). However, no difference in the reduction in leaf-water potential 
Table 1. Effect of galling, plant growth stage and gall age on leaf water potential, photosynthesis, transpiration, and stomatal conductance

\begin{tabular}{|c|c|c|c|c|c|c|c|c|c|}
\hline \multirow[t]{2}{*}{ Source } & \multirow[t]{2}{*}{$\mathrm{df}$} & \multicolumn{2}{|c|}{$\begin{array}{l}\text { Leaf water } \\
\text { potential }\end{array}$} & \multicolumn{2}{|c|}{$\begin{array}{l}\text { Photosynthetic } \\
\text { rate }\end{array}$} & \multicolumn{2}{|c|}{$\begin{array}{l}\text { Transpirational } \\
\text { rate }\end{array}$} & \multicolumn{2}{|c|}{$\begin{array}{l}\text { Stomatal } \\
\text { conductance }\end{array}$} \\
\hline & & $\mathrm{F}$ & $p$ & $\mathrm{~F}$ & $p$ & $\mathrm{~F}$ & $p$ & $\mathrm{~F}$ & $p$ \\
\hline Galling (G) & 1 & 65.1 & $* * *$ & 120.5 & $* * *$ & 603.6 & $* * *$ & 36.6 & $* * *$ \\
\hline Plant stage $(\mathrm{P})$ & 2 & 6.04 & $* *$ & 0.25 & ns & 20.01 & $* * *$ & 0.75 & $\mathrm{~ns}$ \\
\hline Gall age (A) & 1 & 0.92 & ns & 18.14 & $* * *$ & 268.12 & $* * *$ & 6.04 & $*$ \\
\hline $\mathrm{G} \times \mathrm{P}$ & 2 & 8.01 & $* *$ & 7.23 & $* *$ & 7.39 & $* *$ & 3.51 & $*$ \\
\hline $\mathrm{G} \times \mathrm{A}$ & 2 & 0.44 & ns & 4.33 & $*$ & 19.61 & $* * *$ & 4.13 & $*$ \\
\hline $\mathrm{P} \times \mathrm{A}$ & 1 & 0.01 & ns & 0.02 & ns & 8.56 & $* *$ & 0.73 & $\mathrm{~ns}$ \\
\hline $\mathrm{G} \times \mathrm{P} \times \mathrm{A}$ & 2 & 0.45 & ns & 0.96 & ns & 20.06 & $* * *$ & 9.48 & $* * *$ \\
\hline Residual & 48 & & & & & & & & \\
\hline
\end{tabular}

$\mathrm{G}$ galled vs. ungalled plants; $\mathrm{P}$ rosette vs. pre flowering vs. flowering plants; A early stage (7 days) vs. mature stage (12 days) galls.

*Indicates samples are significantly different. ${ }^{*} p<0.01, * * p<0.001, * * * p<0.0001$, ns not significant, and ( $\left.\begin{array}{ll}n & 5\end{array}\right)$.

between early ( 7 days old) and mature galls ( 12 days old) in all growth stages existed (Table 1). The galls alone, as well as gall age had a significant effect on net photosynthetic rate $(p<0.001)$, but the effect of plant-growth stage on net photosynthetic rate was not significant (Figure 1; Table 1). No significant relationship was evident among galling, plant development stage, and gall age on photosynthetic rate (Table 1). In both rosette and pre-flowering stages, galling reduced the net photosynthetic rate by 80 and $87 \%$, respectively, but the interaction between plant stage and gall age was not significant (Figure 1; Table 1). In flowering plants, the reduction in net photosynthetic rate was significantly greater $(92 \%)$ in mature galls (12 days old) than in young galls (7 days old) (Figure 1). Galling significantly reduced $(57 \%)$ the transpiration rate and the reduction was greater in the pre-flowering stage $(68 \%)$ than in the rosette stage $(55 \%)$, and flowering stage $(48 \%)$ (Figure 1; Table 1). The reduction in transpiration rate was statistically higher in mature $(71 \%)$ than in young galls $(43 \%)$ (Figure 1; Table 1). Effect of plant-growth stage on the reduction in stomatal conductance due to galling was not significant (Table 1). Gall showed stomatal conductance reduced by $50 \%$ and the reduction was more in old galls (12 days) (61\%) than in young galls (7 days) (39\%) (Figure 1; Table 1). The effect of plant-growth 
stage on reduction in stomatal conductance due to gall damage was not significant (Table 1).

\section{Mineral concentrations}

Gall incidence significantly increased chloride concentrations in leaves, but had no effect on other minerals tested (Table 2). Interaction between plant-growth stage and plant part had a significant effect on the total chloride, $\mathrm{K}, \mathrm{Mg}, \mathrm{Mn}, \mathrm{N}, \mathrm{P}, \mathrm{S}$, and $\mathrm{Zn}$. Concentrations of $\mathrm{B}, \mathrm{Ca}$, and $\mathrm{Na}$ were affected by plant part only, whereas nitrate was affected by the plant stage (Table 2).

Galling resulted in a $17 \%$ increase in B concentration in leaves of preflowering plants. In flowering plants, chloride concentrations in leaves and stems of galled plants were 42 and $63 \%$ higher, respectively, than in ungalled plants. In pre-flowering plants there were 26 and $44 \%$ increases in chloride concentration in the leaves and stems, respectively, due to galling. In galled flowering plants $\mathrm{Mg}$ concentrations were $32 \%$ higher in leaves, and 30 and 32\% lower in stems and roots, respectively, than in ungalled plants. $\mathrm{Mg}$ content in galled pre-flowering plants was $15 \%$ higher in leaves and $16 \%$ lower in stems than in ungalled pre-flowering plants. In pre-flowering plants, $\mathrm{Zn}$ content was 33 and $26 \%$ higher in leaf and root, respectively, in galled than ungalled plants. In contrast, in preflowering plants, $\mathrm{Zn}$ content of galled stems was $38 \%$ lower than in ungalled stems. Effect of galling by E. strenuana on concentrations of $\mathrm{Ca}$, $\mathrm{Cu}, \mathrm{Fe}, \mathrm{K}, \mathrm{Mn}$, total nitrate, $\mathrm{N}, \mathrm{Na}, \mathrm{P}$, and $\mathrm{S}$ were not significant.

\section{Energetics}

In the pre-flowering and flowering stages of P. hysterophorus, stem tissue from above the gall had significantly lower energy than tissue from below the gall (Figure 2a c). Energy levels of the galls of preflowering stages were not statistically different from adjacent tissues, but galls of flowering plants had higher energy levels than tissue below them and were not statistically different from the tissue above. In rosettestage plants, there was significantly less energy in tissue above the gall than in the gall itself (Figure 2a).

\section{Discussion}

Galling by E. strenuana had negative effects on leaf-water potential, photosynthetic and transpiration rates, stomatal conductance, and also 

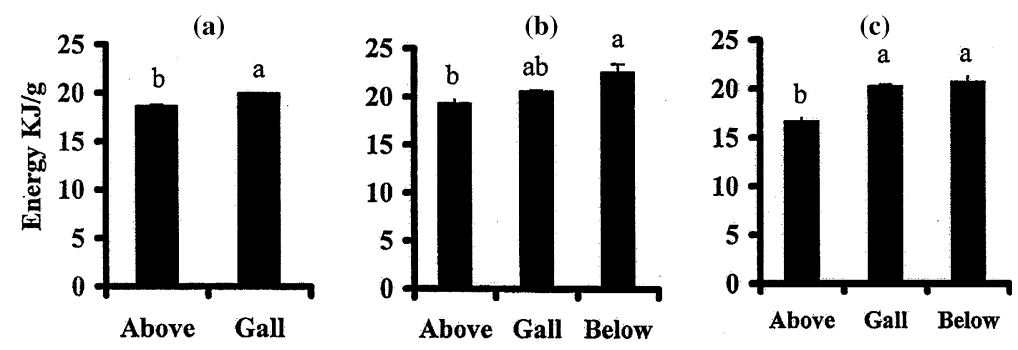

Figure 2. Mean energy levels in stem tissue $1 \mathrm{~cm}$ above the gall, in the gall, and stem tissue $1 \mathrm{~cm}$ below the gall of $P$. hysterophorus (a) rosette, (b) pre flowering, and (c) flowering stages. Same letters indicate means are not statistically different when tested with Tukey's HSD test. Because rosette stage (a) plants develop galls just above the root collar, no data for $1 \mathrm{~cm}$ below the gall was obtained.

increased chloride concentration. Further, leaves of gall-bearing P. hysterophorus plants had higher water potential rates than the ungalled plants. Energy levels in the gall and in the shoot tissue below the gall were also greater than those in the shoot tissue above the gall. All three developmental stages of galled plants showed similar patterns of water use efficiency compared with ungalled plants of similar age, because reduction in $\mathrm{CO}_{2}$ assimilation was followed by a decline in the transpiration rates. Although a $\mathrm{C}_{3}$ plant, metabolism of $P$. hysterophorus has characteristics of transient 'Kranz' syndrome and capabilities of evolution into a $\mathrm{C}_{4}$ plant (Hegde and Patil, 1981). Such capabilities render P. hysterophorus to remain highly adaptive to non-native environments, and thus become invasive (Hegde and Patil, 1981). In this context, the role of E. strenuana in altering $P$. hysterophorus's physiology is noteworthy, because the moth is able to induce changes in the life history performance of the plant (Navie et al., 1998; Dhileepan and McFadyen, 2001).

The feeding action of E. strenuana disrupts the continuity of conductive tissue in $P$. hysterophorus resulting in reduced water movement (Raman and Dhileepan, 1999). Deposition of frass within the gall by the larva clogs the already disrupted vascular tissue. Also, toxins in the frass destroy the potentially regenerative parenchyma elements (Raman and Dhileepan, 1999). Consequently, water-transporting elements of the plant become non-functional. This effect was relatively less severe in galls on rosette and pre-flowering stages than those on the flowering stage, probably because of age-induced changes in tissues and biomass. This finding is contradictory to those reported earlier in which E. strenuana infestations had greater effects on galled plants of the rosette and pre-flowering stages (Dhileepan and McFayden, 1997, 2001). 


\section{PHYSIOLOGICAL RESPONSE OF PARTHENIUM}

High negative water potential readings indicated that the host plant was under water stress. In the water-stressed state, the photosynthetic rate and stomatal conductance of $P$. hysterophorus is reduced; the plant appears to maximize conservation of the available water by reducing transpiration, by closing the stomatal apertures simultaneously (Florentine et al., 2001). Closed stomata impair $\mathrm{CO}_{2}$ uptake resulting in further reduction in the net photosynthetic rate (Warrington et al., 1989). Difficulty in the free movement of water reduces transport of minerals. Accumulation of non-hydrolyzable crystalline starch in the galled tissue (Raman and Dhileepan, 1999) also contributes to a reduction of the host plant's photosynthetic rate (Travis and Prendergast, 1987). Accumulation of crystalline starch in the galled tissue is a unique stress symptom, since Patil and Hegde (1983) have not reported any such accumulation in ungalled $P$. hysterophorus plants. $\mathrm{CO}_{2}$ assimilation generation pattern and water vapour exchange, and gas exchange factors measured as water potential, net photosynthetic rate, stomatal conductance, and transpiration rate have been implicated as critical in the altered metabolism of stressed plants (Evans and von Caemmerer, 1996). Reduction in the rates of transpiration and stomatal conductance in E. strenuana-infested plants was greater than the reduction in net $\mathrm{CO}_{2}$ assimilation, indicating that conductance was a more intensive limiting factor to water vapour exchange than $\mathrm{CO}_{2}$ exchange (Schaffer and Mason, 1990).

Because larvae in galls manipulate the metabolism of the host plant to redirect mineral nutrients required for their growth towards the gall, differences in mineral nutrient concentrations between galled and ungalled plants and within galled plants vary significantly. Gall-inducing insects belonging to different groups seem to require different types and levels of mineral nutrients, and as a result, host plants respond differently to different gall-inducing insects (Bagatto and Shorthouse, 1997). In the galls induced by a pteromalid wasp (Hemadas nubilipennis Ashmead, Hymenoptera), concentrations of $\mathrm{Ca}, \mathrm{Cu}, \mathrm{Mg}, \mathrm{Mn}, \mathrm{Ni}$, and $\mathrm{Zn}$ are different from those in non-galled tissue. The galls act as sinks for $\mathrm{Ca}, \mathrm{Fe}, \mathrm{Mg}, \mathrm{Mn}$, and $\mathrm{Zn}$, in particular (Bagatto and Shorthouse, 1991, 1994; Paquette et al., 1992; St. John and Shorthouse, 2000). Elevated levels of minerals in the gall could be due to either partial blocking of nutrient translocation within the gall (the galls acting as non-mobilizing sinks) or due to active drawing of nutrients and minerals from other parts of the plant (the galls acting as mobilizing sinks) (McCrea et al., 1985). In the E. strenuana-induced galls of P. hysterophorus, galling has a major effect only on chloride and $\mathrm{Mg}$ in the galls, $\mathrm{Mg}$ and $\mathrm{Zn}$ in the leaves and roots of galled plants, and chloride in the leaves of galled 
plants. Varied patterns of change in the concentrations of minerals suggest that the galls induced by E. strenuana act as mobilizing sinks. Such a feature is common in single chamber galls (Paquette et al., 1992), similar to those of E. strenuana because vascular strands occur in close proximity to the nutritive tissue (Raman and Dhileepan, 1999). Absence of any statistical difference in the values of minerals among the three developmental stages suggests that the host plant responds to galling in a similar way irrespective of the developmental stage.

During the early stages of gall development, newly emerged larvae manipulate host plant metabolic pathways and redirect carbohydrates and lipids close to their feeding tissues (Raman and Dhileepan, 1999). The influence of E. strenuana on P. hysterophorus could be seen in the greater concentrations of energy in the gall and stem tissue immediately below the gall than in stem tissue above the gall. These findings are similar to those found in the cecidomyiid-induced galls (Rhopalomyia solidaginis Lw., Diptera) on another asteraceous species (the tall goldenrod, Solidago altissima L.) (Raman and Abrahamson, 1995).

In conclusion, E. strenuana disrupted water movement; induced necrosis in the gall system retarded the mobilization of nutrients beyond the gall, and significantly reduced the gas exchange in P. hysterophorus. These effects demonstrate that the gall moth has potential to regulate the populations of $P$. hysterophorus in Australia.

\section{Acknowledgements}

We thank Rosalyn Blanche (CSIRO, Atherton, Australia), Gary Taylor (University of Adelaide, Glen Osmond, Australia), William Miller (University of Minnesota, Minneapolis, USA), Per Milberg (Linköping University, Linköping, Sweden), and two anonymous referees for constructive comments. Peter Appleford (James Cook University, Townsville, Australia) permitted the use of the bomb calorimeter, and Joe Holtum (James Cook University, Townsville, Australia) provided gas exchange and pressure bomb equipment. The Department of Natural Resources \& Mines (Government of Queensland, Australia) supported this study (R\&D Grant \# NRM/185/001.1221.BV.IT).

\section{References}

Abrahamson, W.G. and A.E. Weis, 1987. Nutritional ecology of arthropod gall makers. In: F. Slansky, Jr. and J.G. Rodriguez (eds), The Nutritional Ecology of Insects, Mites, and Spiders. John Wiley \& Sons, New York, USA. pp. 236258. 


\section{PHYSIOLOGICAL RESPONSE OF PARTHENIUM}

Bagatto, G. and J.D. Shorthouse, 1991. Accumulation of copper and nickel in plant tissues and an insect gall of lowbush blueberry, Vaccinium angustifolium, near an ore smelter at Sudbury, Ontario, Canada. Can. J. Bot. 69: 14831490.

Bagatto, G. and J.D. Shorthouse, 1994. Seasonal acquisition of mineral nutrients by a chalcid gall on lowbush blueberry. Entomol. Exp. Appl. 73: 6166.

Bagatto, G. and J.D. Shorthouse, 1997. Accumulation of mineral nutrients by the galler Hemadas nubilipennis (Hymenoptera: Pteromalidae) and its parasitoids on lowbush blueberry: implications for feeding behaviour. In: A. Raman (ed), Ecology and Evolution of Plant feeding Insects in Natural and Man made Environments. Backhuys Publishers, Leiden, The Netherlands, pp. 159168.

Bronner, R., 1992. The role of nutritive cells in the nutrition of cynipids and cecid omyiids. In: J.D. Shorthouse and O. Rohfritsch. (eds), Biology of Insect induced Galls. Oxford University Press, New York, USA. pp. 118140.

Dhileepan, K. and R.E. McFadyen, 1997. Biological control of parthenium in Australia progress and prospects. In: M. Mahadevappa and V.C. Patil, (eds), Proceedings of the First International Conference on Parthenium Management. The University of Agri cultural Sciences, Dharwad, India. pp. 4044.

Dhileepan, K. and R.E. McFadyen, 2001. Effects of gall damage by the introduced biocontrol agent Epiblema strenuana (Lep., Tortricidae) on the weed Parthenium hysterophorus (Asteraceae). J. Appl. Entomol. 125: 18.

Dhileepan, K., S. Setter and R.E.C. McFadyen, 2000. Response of the weed Parthenium hysterophorus (Asteraceae) to defoliation by the introduced biocontrol agent Zygogramma bicolorata (Coleoptera: Chrysomelidae). Biol. Control 19: 916.

Dreger Jauffret, F. and J.D. Shorthouse, 1992. Diversity of gall inducing insects and their galls. In: J.D. Shorthouse and O. Rohfritsch (eds), Biology of Insect induced Galls. Oxford University Press, New York, USA. pp. 833.

Evans, J.R. and S. von Caemmerer, 1996. $\mathrm{CO}_{2}$ diffusion inside leaves. Plant Physiol. 110: 339346.

Fay, P.A., D.C. Hartnett and D.C. Knapp, 1993. Increased photosynthesis and water potential in Silphium integrifolium galled by cynipid wasps. Oecologia 93: 114120.

Flinn, P.W., A.A. Hower and D.P. Knievel, 1990. Physiological response of alfalfa to injury by Empoasca fabae (Homoptera: Cicadellidae). Environ. Entomol. 19: 176181

Florentine, S.K., A. Raman and K. Dhileepan, 2001. Gall inducing insects and biological control of Parthenium hysterophorus L. (Asteraceae). Plant Prot. Q. 16: 6368.

Florentine, S.K., A. Raman and K. Dhileepan, 2002. Responses of the weed Parthenium hysterophorus (Asteraceae) to the stem gall inducing weevil Conotrachelus albocine reus (Coeoptera: Curculionidae). Entomol. Gen. 26: 195206.

Hegde, B.A. and T.M. Patil, 1981. Parthenium hysterophorus (L.): a $\mathrm{C}_{3}$ plant with 'Kranz' syndrome. Photosynthetica 15: 14.

Kirst, G.O. and H. Rapp, 1974. Zur Physiologie der Galle von Mikiola fagi Htg. auf Blättern von Fagus silvatica L. 2. Transport ${ }^{14} \mathrm{C}$ markierter Assimilate aus dem befallenen Blatt und aus Nachbarblättern in der Galle. Biochem. Physiol. Pflanzen 165: 445455.

Lalonde, R.G. and J.D. Shorthouse, 1984. Developmental morphology of the gall of Urophora cardui (Diptera: Tephritidae) in the stems of Canada thistle (Cirsium ar vense). Can. J. Bot. 62: 13721384.

Larson K.C., 1998. The impact of two gall forming arthropods on the photosynthetic rates of their hosts. Oecologia 115: 161166. 


\section{S.K. FLORENTINE ET AL.}

Larson K.C. and T.G. Whitham, 1991. Manipulation of food resources by a gall forming aphid: the physiology of source sink interactions. Oecologia 88: 1521.

McCrea, K.D., W.G. Abrahamson and A.E. Weis, 1985. Goldenrod ball gall effects of Solidago altissima: $\mathrm{C}^{14}$ translocation and growth. Ecology 66: 19021907.

McFadyen R.E., 1992. Biological control against parthenium weed in Australia. Crop Prot. 24: 400407.

McQuacker N.R., D.F. Brown and P.D. Kluckner, 1979. Digestion of environmental materials for analysis by inductively coupled plasma atomic emission spectrometry. Anal. Chem. 51: 10821084.

Navie, S.C., R.E. McFadyen, F.D. Panetta and S.W. Adkins, 1996. The biology of Australian weeds. 27. Parthenium hysterophorus L. Plant Prot, Q 11: 7688.

Navie, S.C., T.E. Priest, R.E. McFadyen and S.W. Adkins, 1998. Efficacy of the stem galling moth Epiblema strenuana Walk. (Lepidoptera: Tortricidae) as a biological control agent for the ragweed parthenium (Parthenium hysterophorus L.). Biol Control 13: 18 .

Paquette, L.C., G. Bagatto and J.D. Shorthouse, 1992. Distribution of mineral nutrients within the leaves of common dandelion (Taraxacum officinale) galled by Phanacis taraxci (Hymenoptera: Cynipidae). Can. J. Bot. 71: 10261031.

Patil, T.M. and B.A. Hegde, 1983. Pattern of starch distribution, carbon dioxide con centration and photochemical reduction of tetranitro tetrazolium blue in Parthenium hysterophorus L. Photosynthetica 17: 6468.

Raman, A., 1994. Adaptational integration between gall inducing insects and their host plants. In: T.N. Ananthakrishnan (ed), Functional Dynamics of Phytophagous In sects. Oxford \& IBH Publishing Company, New Delhi, India. pp. 249276.

Raman, A., 1996. Nutritional diversity in gall inducing insects and their evolutionary relationships with flowering plants. Int. J. Ecol. Environ. Sci. 22: 150160.

Raman, A. and W.G. Abrahamson, 1995. Morphometric relationships and energy allocation in the apical rosette galls of Solidago altissima (Asteraceae) induced by Rhopalomyia solidaginis (Diptera: Cecidomyiidae). Environ. Entomol. 24: 635639.

Raman, A. and K. Dhileepan, 1999. Qualitative evaluation of damage by Epiblema strenuana (Lepidoptera: Tortricidae) to the weed Parthenium hysterophorus (Aster aceae). Ann. Entomol. Soc. Am. 92: 717723.

Rohfritsch, O., 1988. Food supply mechanism related to gall structure, the example of Geocrypta galii Lw. (Cecidomyiidae, Oligotrophini) on Galium mollugo. Phytophaga 2: 117.

Schaffer, B. and L.J. Mason, 1990. Effects of scale insect herbivory and shading on net gas exchange and growth of a subtropical tree species (Guaiacum sanctum L.). Oecologia 84: 468473.

Scholander, P.F., H.T. Hammel, E.A. Hemmingsen and E.D. Bradstreet, 1965. Hydrostatic pressure and osmotic potential in leaves of mangroves and some other plants. Proc. Natl. Acad. Sci. USA 52: 119125.

Shorthouse, J.D. and O. Rohfritsch, 1992. Biology of Insect induced Galls. Oxford University Press, New York, USA.

St John, M.G. and J.D. Shorthouse, 2000. Allocation patterns of organic nitrogen and mineral nutrients within stem galls of Diplolepis spinosa and Diplolepis triforma (Hymenoptera: Cynipidae) on wild roses (Rosaceae). Can. Entomol. 132: 635648.

Sweeney, R.A. and P.R. Rexroad, 1987. Comparison of LECO FP 228 'nitrogen deter mination' with AOAC copper catalyst Kjeldahl method for crude protein. J. Assoc. Off. Anal. Chem. 70: 10281039. 


\section{PHYSIOLOGICAL RESPONSE OF PARTHENIUM}

Travis, R.L. and J. Prendergast, 1987. Effect of leaf sugar and starch concentrations on apparent photosynthesis in alfalfa. J. Agron. Crop Sci 159: 51-58.

Warrington, S., D.A. Cottam and J.B. Whittaker, 1989. Effects of insect damage on photosynthesis, transpiration and $\mathrm{SO}_{2}$ uptake by sycamore. Oecologia 80: 136-139.

Wolf, B., 1974. Improvement in the azomethine-H method for the determination of Boron. [Soil]. Commun. Soil Sci. Plant Anal. 5: 39-44.

Zall, D.M., D. Fisher and M.Q. Garner, 1959. Photometric determination of chloride in water. Anal. Chem. 28: 1665-1668. 